\title{
PENGARUH METODE QIRAATI TERHADAP KEMAMPUAN MEMBACA AL-QUR'AN ANAK USIA 7-12 TAHUN DI TAMAN PENDIDIKAN AL-QUR'AN (TPQ) HIDAYATUS SHIBYAN DESA PEGAGAN LOR KECAMATAN KAPETAKAN KABUPATEN CIREBON
}

\author{
Dian Nopiyanti, Abdul Ghofar, Nawawi \\ Fakultas Ilmu Tarbiyah dan Keguruan \\ Institut Agama Islam Negeri Syekh Nurjati Cirebon \\ Email : nopiyantidian0511@gmail.com
}

\begin{abstract}
ABSTRAK
Penggunaan metode Qiraati di Taman Pendidikan Al-Qur'an (TPQ) Hidayatus Shibyan sudah diterapkan dengan baik. Kendati demikian pada kenyataannya di lapangan, peneliti masih menemukan anak yang lambat dan terbata-bata dalam membaca Al-Qur'annya.Di sisi lain masih ada anak yang belum fokus saat mengikuti proses pembelajaran berlangsung. Hal ini sangat mempengaruhi kemampuan membaca Al-Qur'annya.

Tujuan penelitian ini adalah: 1) Untuk mengetahui penerapan metode Qiraati dalam pengajaran ilmu baca Al-Qur'an di Taman Pendidikan Al-Qur'an (TPQ) Hidayatus ShibyanDesa Pegagan Lor Kecamatan Kapetakan Kabupaten Cirebon. 2) Untuk mengetahui kemampuan membaca Al-Qur'an anak usia 7-12 tahun diTaman Pendidikan Al-Qur'an (TPQ) Hidayatus ShibyanDesa Pegagan Lor Kecamatan Kapetakan Kabupaten Cirebon. 3) Untuk mengetahui seberapa besar pengaruh penerapan metode Qiraati terhadap kemampuan membaca AlQur'an anak usia 7-12 tahun di Taman Pendidikan Al-Qur'an (TPQ) Hidayatus ShibyanDesa Pegagan Lor Kecamatan Kapetakan Kabupaten Cirebon.

Penelitian ini bertolak dari pemikiran bahwa pemilihan metode yang tepat dalam mengajarkan ilmu baca Al-Qur'an akan sangat membantu proses belajar mengajar menjadi mudah serta dapat meningkatkan kemampuan membaca AlQur'an menjadi lebih baik.

Pendekatan penelitian yang digunakan dalam skripsi ini adalah pendekatan kuantitatif yang menggunakan lima teknik pengumpulan data yaitu: 1)
\end{abstract}


Observasi, 2) Wawancara 3) Angket, 4) Tes lisan, dan 5) Dokumentasi. Sedangkan untuk menganalisa data yang diperoleh peneliti menggunakan reduksi data, penyajian data, kesimpuan gambaran, statistik deskriptif, dan rumus product moment.

Kesimpulan penelitian menunjukan bahwa penerapan metode Qiraati di Taman Pendidikan Al-Qur'an (TPQ) Hidayatus Shibyan telah dilaksanakan dengan baik dengan nilai 79 karena berada pada interval 75\%-100\%. Sementara itu, kemampuan membaca Al-Qur`an anak usia 7-12 tahun dalam kategori baik, terbukti dengan rekapitulasi hasil tes kemampuan membaca Al-Qur'an ini, menunjukkan nilai rata-ratanya 70 karena berada pada interval 70-79. Dan pengaruh metode Qiraati terhadap kemampuan membaca Al-Qur'an anak usia 712 tahun di Taman Pendidikan Al-Qur'an (TPQ) Hidayatus Shibyan berdasarkan hasil perhitungan dengan menggunakan product moment yang diperoleh besarnya $r_{x y}$ adalah 0,62 yang berarti tergolong sedang karena pada interval 0,40-0,70. Apabila dihitung hasil $t_{\text {hitung }}$ dengan $t_{\text {tabel }}$ yaitu didapat $t_{\text {hitung }} \geq t_{\text {tabel }}$ atau 5,44>2,75 maka Ho ditolak dan Ha diterima artinya tedapat pengaruh dalam penerapan metode terhadap kemampuan membaca Al-Qur'an anak usia 7-12 tahun di Taman Pendidikan Al-Qur'an (TPQ) Hidayatus Shibyan Desa Pegagan Lor Kecamatan Kapetakan Kabupaten Cirebon.

Kata Kunci: Metode Qiraati dan Kemampuan Membaca Al-Qur'an 


\section{PENDAHULUAN}

Metode Qiraati adalah suatu metode membaca Al-Qur'an yang langsung memasukkan dan mempraktekkan bacaan tartil sesuai dengan kaidah ilmu tajwid. Metode Qiraati terdapat dua pokok yang mendasari, yakni: membaca Al-Qur'an secara langsung dan membiasakan membaca Al-Qur'an dengan tartil sesuai dengan kaidah ilmu tajwid. Metode Qiraati ini memungkinkan anak-anak mempelajari Al-Qur'an secara cepat, tepat dan benar.

Kegiatan pengajaran ilmu baca Al-Qur'an dengan metode Qiraati ini mempunyai filosofi tersendiri, supaya memudahkan anak-anak dalam belajar membaca Al-Qur'an. Filososfi metode Qiraati ini di antaranya:

1) Sampaikanlah materi pelajaran secara praktis, simpel dan sederhana sesuai dengan bahasa yang dapat dimengerti oleh anak-anak, jangan terlalu rumit dan berbelit-belit.

2) Berikanlah materi pelajaran secara bertahap dan dengan penuh kesabaran.

3) Jangan mengajarkan yang salah kepada anak-anak, karena mengajarkan yang benar itu mudah. (Imam Murjito, 2000:23).

Menurut Imam Murjito (2000:59) menilai bahwa masih banyak ditemukan beberapa faktor kesalahan atau kekeliruan guru dalam mengajarkan membaca AlQur'an, yakni:

1. Guru tidak mengetahui ukuran atau standar bacaan Al-Qur'an yang benar sesuai kaidah ilmu tajwid.

2. Guru tidak membiasakan bacaan yang benar kepada dirinya sendiri dan kepada murid-muridnya.

3. Guru tidak mengetahui dan tidak menguasai metode pengajaran ilmu baca AlQur'an secara tepat dan benar.

4. Guru terlalu gegabah atau sembarangan dalam mengajarkan ilmu baca AlQur'an kepada murid-muridnya.

5. Kurang mengerti dan kurang memahami kondisi dan kemampuan muridmuridnya.

Jika kualitas dan kemampuan guru dalam mengajarkan ilmu baca AlQur'an kurang, maka secara tidak langsung ia akan merusak kehormatan, kesucian dan kemurnian Al-Qur'an, juga secara tidak langsung akan 
menghancurkannya. Apabila suatu urusan diserahkan kepada orang yang bukan ahlinya, terutama urusan agama, maka bukan saja membuat orang lain sesat di dunia, tetapi dapat membuat orang lebih sengsara di akhirat nanti. Oleh sebab itu, peranan seorang pembimbing atau guru ngaji sangat dibutuhkan. Seorang pembimbing atau guru ngaji haruslah yang berkompeten dalam membaca AlQur'an, karena kualitas seorang guru akan berpengaruh terhadap kemampuan bacaan muridnya.

Metode Qiraati mempunyai tujuan agar dalam pengajarannya dapat berjalan dengan baik sesuai dengan tuntutan ibadah sebagaimana yang dikehendaki oleh Allah SWT dan Rasul-Nya. Tujuan metode Qiraati menurut Imam Murjito (2000: 17-18) adalah sebagai berikut:

1) Menjaga dan memelihara kehormatan, kesucian dan kemurnian Al-Qur'an dari cara membaca yang benar, sesuai kaidah tajwid sebagaimana bacaannya Nabi Muhammad SAW.

2) Menyebarluaskan ilmu baca Al-Qur'an yang benar dengan cara yang benar.

3) Mengingatkan kepada guru-guru Al-Qur'an agar dalam mengajarkan AlQur'an harus berhati-hati, jangan sembarangan.

4) Meningkatkan mutu (kualitas) pendidikan ilmu pengajaran Al-Qur'an.

Kemampuan membaca Al-Qur'an dapat diartikan dengan kesanggupan dan kecakapan melafalkan bacaan ayat-ayat Al-Qur'an dengan baik dan benar yaitu sesuai dengan tuntunan ilmu tajwid. Kemampuan membaca Al-Qur'an dapat dipengaruhi oleh dua faktor, yakni yang datang dari dalam diri siswa erat kaitannya dengan psikologi, mencakup minat dan motivasi. Sedangkan faktor yang datang dari luar meliputi lingkungan, sarana dan prasarana, kurikulum, guru, teknik (metode) mengajar serta fasilitas pendukung lainnya.

Diantara bentuk pendidikan islam yang diajarkan adalah membaca AlQur'an misalnya. Membaca Al-Qur'an merupakan bentuk pendidikan Islam yang harus diterapkan sejak dini. Dengan membaca Al-Qur'an sedini mungkin, anak masih mempunyai banyak kesempatan untuk melakukan segala aktivitas yang berkenaan dengan pengetahuan belajar Al-Qur'an. Hal ini bertujuan agar anak mulai tertanam di hatinya nilai-nilai ajaran Islam dan perhatiannya terhadap 
kecintaan dalam mempelajari Al-Qur'an sejak masih kecil, sehingga ketika dewasa nanti anak akan terhindar dari hal-hal yang dapat merugikan dirinya atau orang lain.

Imam Al-Sayuti mengatakan bahwa mengajarkan Al-Qur'an pada anakanak merupakan salah satu diantara pilar-pilar Islam, sehingga mereka bisa tumbuh di atas fitrah. Begitu cahaya hikmah akan terlebih dahulu masuk ke dalam hati mereka, sebelum dikuasai oleh hawa nafsu dan dinodai oleh kemaksiatan dan kesesatan. (Muhammad Nur Abdul Hafidz, 2003: 157-158).

Membaca Al-Qur'an dalam Islam, tergolong amalan yang banyak mendatangkan manfaat dan kebaikan di dunia maupun di akhirat kelak bagi orang yang melakukannya. Kebaikan di dunia bagi orang yang membaca Al-Qur'an dapat terhindar dari segala godaan syaitan yang akan menyesatkan hidupnya, sedangkan kebaikan di akhirat adalah orang yang banyak membaca Al-Qur'an akan mendapat pembelaan di akhirat kelak. Pengenalan membaca Al-Qur'an tidak berhenti dalam ruang lingkup keluarga. Akan tetapi dikenalkan kembali pada pendidikan sekolah non formal di Taman Pendidikan Al-Qur'an (TPQ).

Meningkatkan kemampuan membaca Al-Qur'an anak-anak salah satunya melalui metode Qiraati. Metode Qiraati pertama kali disusun oleh KH. Dachlan Salim Zarkasyi dari Semarang Jawa Tengah Indonesia. Metode Qiraati adalah salah satu metode yang secara langsung tanpa dieja dan membiasakan membaca secara tartil sesuai dengan kaidah ilmu tajwid. Untuk mencapai tujuan tersebut, guru yang akan mengajarkan ilmu baca Al-Qur'an dengan menggunakan metode Qiraati syaratnya adalah guru tersebut harus ditashih terlebih dahulu bacaan AlQur'annya, sehingga dapat layak mengajar atau tidak.

Taman Pendidikan Al-Qur'an (TPQ) adalah lembaga atau kelompok masyarakat yang menyelenggarakan pendidikan non formal jenis keagamaan Islam yang bertujuan untuk memberikan pengajaran membaca Al-Qur'an sejak usia dini, serta memahami dasar-dasar dinul Islam. Di mana kurikulumnya ditekankan pada pemberian dasar-dasar membaca Al-Qur'an serta membantu pertumbuhan dan perkembangan rohani anak agar memiliki kesiapan dalam memasuki pendidikan lebih lanjut. 
Berdasarkan study pendahuluan yang dilakukan peneliti tanggal 18 April 2017 di Taman Pendidikan Al-Qur'an (TPQ) Hidayatus Shibyan. Bahwasannya penggunaan metode Qiraati di Taman Pendidikan Al-Qur'an (TPQ) Hidayatus Shibyan sudah diterapkan dengan baik. Kendati demikian pada kenyataannya di lapangan, peneliti masih menemukan anak yang lambat dan terbata-bata dalam membaca Al-Qur'annya.Di sisi lain masih ada anak yang belum fokus saat mengikuti proses pembelajaran berlangsung. Hal ini sangat mempengaruhi kemampuan membaca Al-Qur'annya.

Uraian latar belakang di atas, peneliti terdorong untuk mengadakan penelitian dengan judul "Pengaruh Metode Qiraati terhadap Kemampuan Membaca Al-Qur'an Anak Usia 7-12 Tahun di Taman Pendidikan Al-Qur'an (TPQ) Hidayatus Shibyan Desa Pegagan Lor Kecamatan Kapetakan Kabupaten Cirebon".

Berdasarkan latar belakang di atas, dapat penulis uraikan rumusan masalah sebagai berikut: (1) Apakah penerapan metode Qiraati dalam pengajaran ilmu baca Al-Qur'an di Taman Pendidikan Al-Qur'an (TPQ) Hidayatus Shibyan Desa Pegagan Lor Kecamatan Kapetakan Kabupaten Cirebon dapat dilaksanakan dengan baik? (2)Apakah kemampuan membaca Al-Qur'an anak usia 7-12 Tahun di Taman Pendidikan Al-Qur'an (TPQ) Hidayatus Shibyan Desa Pegagan Lor Kecamatan Kapetakan Kabupaten Cirebon dikategorikan baik dengan menggunakan metode Qiraati? (3) Seberapa besar pengaruh metode Qiraati terhadap kemampuan membaca Al-Qur'an anak usia 7-12 tahun di Taman Pendidikan Al-Qur'an (TPQ) Hidayatus Shibyan Desa Pegagan Lor Kecamatan Kapetakan Kabupaten Cirebon?.

Setiap kegiatan yang dilakukan harus memiliki tujuan yang jelas. Begitu pula dengan penelitian ini, yang bertolak pada rumusan masalah. Penelitian ini dilaksanakan dengan tujuan: (1) Untuk mengetahui penerapan metode Qiraati dalam pengajaran ilmu baca Al-Qur'an di Taman Pendidikan Al-Qur'an (TPQ) Hidayatus Shibyan Desa Pegagan Lor Kecamatan Kapetakan Kabupaten Cirebon. (2) Untuk mengetahui kemampuan membaca Al-Qur'an anak usia 7-12 tahun di Taman Pendidikan Al-Qur'an (TPQ) Hidayatus Shibyan Desa Pegagan Lor Kecamatan Kapetakan Kabupaten Cirebon setelah menggunakan metode Qiraati. 
(3) Untuk mengetahui seberapa besar pengaruh metode Qiraati terhadap kemampuan membaca Al-Qur'an anak usia 7-12 tahun di Taman Pendidikan AlQur'an (TPQ) Hidayatus Shibyan Desa Pegagan Lor Kecamatan Kapetakan Kabupaten Cirebon.

\section{PEMBAHASAN}

Secara literal, metode berasal dari bahasa Greek yang terdiri dari dua kosa kata, yaitu meta yang berarti melalui dan hodos yang berarti jalan. Metode, dengan demikian, berarti jalan yang dilalui. Secara teknis metode berarti prosedur yang dipakai untuk mencapai suatu tujuan. Atau juga ilmu pengetahuan dari suatu materi tertentu. Atau juga ilmu pengetahuan yang merumuskan aturan-aturan dari suatu prosedur. (Suteja, 2015: 127).

Qiraati artinya "bacaanku” secara bahasa Arab merupakan kata dasar atau masdar. Masdar yang disandarkan pada Ya Mutakalim, artinya "bacaanku", yang bermakna “inilah bacaanku (bacaan Al-Qur'an) yang baik dan benar sesuai dengan kaidah ilmu tajwid”. (Imam Murjito, 2000: 9).

Berdasarkan uraian di atas, penulis menyimpulkan bahwa metode Qiraati adalah suatu metode membaca Al-Qur'an yang langsung memasukkan dan mempraktekkan bacaan tartil sesuai dengan kaidah ilmu tajwid, dan memungkinkan anak-anak dapat mempelajari membaca Al-Qur'an secara cepat, tepat dan benar.

Kemampuan membaca Al-Qur'an dapat diartikan dengan kesanggupan dan kecakapan melafalkan bacaan ayat-ayat Al-Qur'an dengan baik dan benar yaitu sesuai dengan tuntunan ilmu tajwid. Kemampuan membaca Al-Qur'an dapat dipengaruhi oleh dua faktor, yakni yang datang dari dalam diri siswa erat kaitannya dengan psikologi, mencakup minat dan motivasi. Sedangkan faktor yang datang dari luar meliputi lingkungan, sarana dan prasarana, kurikulum, guru, teknik (metode) mengajar serta fasilitas pendukung lainnya.

Kegiatan pengajaran ilmu baca Al-Qur'an dengan metode Qiraati ini mempunyai filosofi tersendiri, supaya memudahkan anak-anak dalam belajar membaca Al-Qur'an. Filososfi metode Qiraati ini di antaranya: 
1) Sampaikanlah materi pelajaran secara praktis, simpel dan sederhana sesuai dengan bahasa yang dapat dimengerti oleh anak-anak, jangan terlalu rumit dan berbelit-belit.

2) Berikanlah materi pelajaran secara bertahap dan dengan penuh kesabaran.

3) Jangan mengajarkan yang salah kepada anak-anak, karena mengajarkan yang benar itu mudah. (Imam Murjito, 2000: 23).

Metode Qiraati sangatlah berperan terhadap kemampuan membaca AlQur'an anak, dan diharapkan dapat memberikan kontribusi dalam membangkitkan minat anak-anak Taman Pendidikan Al-Qur'an Hidayatus Shibyan Desa Pegagan Lor Kecamatan Kapetakan Kabupaten Cirebon dalam belajar membaca AlQur'an, serta dapat meningkatkan mutu (kualitas) pendidikan ilmu pengajaran AlQur'an menjadi lebih baik.

\section{METODOLOGI PENELITIAN}

Berdasarkan uraian di atas terkait teori tentang metode Qiraati dan kemampuan membaca Al-Qur'an, maka untuk mengetahui jawaban dari permasalahan yang telah penulis sampaikan, penulis menentukan perihal metodologi penelitiannya. Penelitian jenis kuantitatif ini menggunakan Random Sampling, dengan teknik pengumpulan data observasi, wawancara, angket, tes lisan tentang kemampuan membaca Al-Qur'an dan studi dokumentasi.Adapun analisis datanya menggunakan rumus product moment.Populasi dalam penelitian ini yaitu 125 anak dengan 11 kelas dan sampelnya 1 kelas sebanyak 31 anak.

\section{ANALISIS DATA HASIL PENELITIAN}

Adapun hasil dari analisis data yang penulis lakukan diperoleh data sebagai berikut:

1. Penerapan Metode Qiraati di Taman Pendidikan Al-Qur'an (TPQ) Hidayatus Shibyan Desa Pegagan Lor Kecamatan Kapetakan Kabupaten Cirebon

Penelitian ini bertujuan untuk mengetahui penerapan metode Qiraati di Taman Pendidikan Al-Qur'an (TPQ) Hidayatus Shibyan Desa Pegagan Lor 
Kecamatan Kapetakan Kabupaten Cirebon, yang dilakukan dengan menyebarkan angket kepada 31 orang responden yang merupakan $25 \%$ dari populasi yang berjumlah 125 anak. Angket yang disebar, terdiri dari 20 pernyataan variabel $\mathrm{X}$, sehingga berjumlah 20 item pernyataan.

Tabel 1. Rekapitulasi Rata-Rata Hasil Angket Penerapan Metode Qiraati

\begin{tabular}{|c|c|c|}
\hline No & Variabel & Rata-rata $(\bar{\chi})$ \\
\hline 1 & \multirow{20}{*}{$\begin{array}{c}\text { Selalu } \\
\text { Sering } \\
\text { Kadang-kadang } \\
\text { Tidak Pernah }\end{array}$} & 2,80 \\
\hline 2 & & 3,12 \\
\hline 3 & & 3,41 \\
\hline 4 & & 3,06 \\
\hline 5 & & 3,61 \\
\hline 6 & & 3,29 \\
\hline 7 & & 3,16 \\
\hline 8 & & 2,83 \\
\hline 9 & & 3,25 \\
\hline 10 & & 3,12 \\
\hline 11 & & 3,16 \\
\hline 12 & & 2,90 \\
\hline 13 & & 3,25 \\
\hline 14 & & 3,16 \\
\hline 15 & & 3,61 \\
\hline 16 & & 3,29 \\
\hline 17 & & 3,09 \\
\hline 18 & & 2,67 \\
\hline 19 & & 3,29 \\
\hline 20 & & 3,06 \\
\hline & lah & 63,13 \\
\hline
\end{tabular}

1. Menentukan rata-rata: $=\frac{\bar{\chi}}{\text { Banyaknya item angket }}=\frac{63,13}{20}=3,16$

2. Menentukan kategori : $\frac{\text { Rata }- \text { rata }}{\text { Skor Maksimal }} \times 100 \%=\frac{3,16}{4} \times 100 \%=$ $79 \%$ 
Berdasarkan rekapitulasi rata-rata hasil angket (variabel $\mathrm{X}$ ) mengenai penerapan metode Qiraati pada pengajaran ilmu baca Al-Qur'an, maka dapat diambil kesimpulan bahwa penerapan metode Qiraati di Taman Pendidikan Al-Qur'an (TPQ) Hidayatus Shibyan ini termasuk dalam kategori baik, dengan nilai 79\% karena berada pada interval 75\%$100 \%$

2. Kemampuan Membaca Al-Qur'an Anak Usia 7-12 Tahun di Taman Pendidikan Al-Qur'an (TPQ) Hidayatus Shibyan Desa Pegagan Lor Kecamatan Kapetakan Kabupaten Cirebon

Penelitian ini bertujuan untuk mengetahui keadaan kemampuan membaca Al-Qur'an anak usia 7-12 tahun di Taman Pendidikan Al-Qur'an (TPQ) Hidayatus Shibyan, yang menggunakan tes lisan yaitu dengan cara membaca Al-Qur'an. Peneliti menentukan penilaian berdasarkan kemampuan anak dalam membaca Al-Qur'an yang dibimbing oleh guru.

Tabel 2. Hasil Tes Kemampuan Membaca Al-Qur'an

\begin{tabular}{|c|l|c|c|}
\hline No & \multicolumn{1}{|c|}{ Nama } & $\begin{array}{c}\text { Nilai Tes } \\
\text { Lisan }\end{array}$ & Kategori \\
\hline 1 & Abdullah Wahid & 75 & Baik \\
\hline 2 & Amira Verial & 65 & Cukup \\
\hline 3 & Audrey Aprilia Putri & 75 & Baik \\
\hline 4 & Aulia Asfa & 65 & Cukup \\
\hline 5 & Cindy Nurrahma Alini & 70 & Baik \\
\hline 6 & Dicky Maulana Putra Junedi & 60 & Cukup \\
\hline 7 & Falih Harofi Khazen & 65 & Cukup \\
\hline 8 & Fatima Azzahra & 60 & Cukup \\
\hline 9 & Heni Anggraeni & 55 & Kurang \\
\hline 10 & Jihan Sabrina Ramadhani & 70 & Baik \\
\hline 11 & Julfa & 65 & Cukup \\
\hline 12 & kafilah Dwi Aryani & 65 & Cukup \\
\hline 13 & Lamim Mustofid & 75 & Baik \\
\hline 14 & Moh. Evin Nugraha & 75 & Baik \\
\hline 15 & Moh. Hendri Aunillah & 75 & Baik \\
\hline 16 & Muhammad Fajar Sydiq & 70 & Baik \\
\hline 17 & Najmah Almira & 60 & Cukup \\
\hline 18 & Nurfaidah & 75 & Baik \\
\hline
\end{tabular}




\begin{tabular}{|c|l|c|c|}
19 & Rahmat Hidayat & 75 & Baik \\
\hline 20 & Raihana Indi Faiha & 60 & Cukup \\
\hline 21 & Revaldy Prastiyo & 60 & Cukup \\
\hline 22 & Salsa Atyaliani & 70 & Baik \\
\hline 23 & Shinta Kartika Putri & 70 & Baik \\
\hline 24 & Suhailah Azahri & 70 & Baik \\
\hline 25 & Syafiqah Novelya Prorin & 80 & Sangat Baik \\
\hline 26 & Syahal Mubarok & 70 & Baik \\
\hline 27 & Talita Azalia Putri & 80 & Sangat Baik \\
\hline 28 & Ube Dillah & 80 & Sangat Baik \\
\hline 29 & Uni Nurandine Marline & 80 & Sangat Baik \\
\hline 30 & Veni Suryawati & 80 & Sangat Baik \\
\hline 31 & Wizahra & 75 & Baik \\
\hline Jumlah & 2170 & \\
\hline
\end{tabular}

Tabel 3. Data Perhitungan Kemampuan Membaca Al-Qur'an

\begin{tabular}{|l|c|c|}
\hline \multirow{2}{*}{ Nilai } & \multicolumn{2}{|c|}{ Tes Lisan } \\
\cline { 2 - 3 } & Frekuensi & Skor Rata-Rata \\
\hline A (Sangat Baik) & 5 & $16,13 \%$ \\
\hline B (Baik) & 15 & $48,39 \%$ \\
\hline C (Cukup) & 10 & $32,26 \%$ \\
\hline D (Kurang) & 1 & $3,22 \%$ \\
\hline \multicolumn{1}{|c|}{ Jumlah } & 31 & $100 \%$ \\
\hline
\end{tabular}

Statistics

\begin{tabular}{|lr|r|}
\hline N $\quad$ Valid & 31 \\
Mean & Missing & 0 \\
Median & 70,00 \\
Mode & 70,00 \\
Sum & 75 \\
\hline
\end{tabular}

Dapat disimpulkan bahwa nilai kemampuan membaca Al-Qur'an anak usia 7-12 tahun di Taman Pendidikan Al-Qur'an (TPQ) Hidayatus Shibyan Desa Pegagan Lor Kecamatan Kapetakan Kabupaten Cirebon, termasuk kategori baik. Hal ini dapat dilihat pula dari nilai rata-ratanya (mean) yaitu 70 karena berada pada interval $70-79$. 
3. Pengaruh Metode Qiraati terhadap Kemampuan Membaca Al-Qur'an Anak Usia 7-12 Tahun di Taman Pendidikan Al-Qur'an (TPQ) Hidayatus Shibyan Desa Pegagan Lor Kecamatan Kapetakan Kabupaten Cirebon

Penelitian ini untuk mengetahui seberapa besar pengaruh dari penerapan metode Qiraati sebagai variabel (X) terhadap kemampuan membaca Al-Qur'an sebagai variabel (Y), maka penulis sajikan kedua data variabel yang diperoleh dari hasil angket dan tes kemampuan membaca AlQur'anterhadap 31 anak sebagai responden. Kemudian akan dikorelasikan dengan menggunakan rumus korelasi product moment.Adapun data yang dimaksud dapat dilihat pada tabel di bawah ini.

Tabel 4. Perhitungan Korelasi Product Moment antara Penerapan Metode Qiraati (Variabel X) dengan

Kemampuan Membaca Al-Qur'an (Variabel Y)

\begin{tabular}{|c|c|c|c|c|c|}
\hline No & $\mathrm{X}$ & $\mathrm{Y}$ & $\mathrm{X} 2$ & $\mathrm{Y} 2$ & $\mathrm{XY}$ \\
\hline 1 & 70 & 75 & 4900 & 5625 & 5250 \\
\hline 2 & 55 & 65 & 3025 & 4225 & 3575 \\
\hline 3 & 67 & 75 & 4489 & 5625 & 5025 \\
\hline 4 & 45 & 65 & 2025 & 4225 & 2925 \\
\hline 5 & 57 & 70 & 3249 & 4900 & 3990 \\
\hline 6 & 56 & 60 & 3136 & 3600 & 3360 \\
\hline 7 & 60 & 65 & 3600 & 4225 & 3900 \\
\hline 8 & 54 & 60 & 2916 & 3600 & 3240 \\
\hline 9 & 45 & 55 & 2025 & 3025 & 2475 \\
\hline 10 & 65 & 70 & 4225 & 4900 & 4550 \\
\hline 11 & 60 & 65 & 3600 & 4225 & 3900 \\
\hline 12 & 55 & 65 & 3025 & 4225 & 3575 \\
\hline 13 & 65 & 75 & 4225 & 5625 & 4875 \\
\hline 14 & 60 & 75 & 3600 & 5625 & 4500 \\
\hline 15 & 58 & 75 & 3364 & 5625 & 4350 \\
\hline 16 & 50 & 70 & 2500 & 4900 & 3500 \\
\hline 17 & 65 & 60 & 4225 & 3600 & 3900 \\
\hline 18 & 65 & 75 & 4225 & 5625 & 4875 \\
\hline 19 & 67 & 75 & 4489 & 5625 & 5025 \\
\hline 20 & 56 & 60 & 3136 & 3600 & 3360 \\
\hline 21 & 52 & 60 & 2704 & 3600 & 3120 \\
\hline 22 & 64 & 70 & 4096 & 4900 & 4480 \\
\hline & & & & & \\
\hline
\end{tabular}




\begin{tabular}{|c|c|c|c|c|c|}
\hline 23 & 67 & 70 & 4489 & 4900 & 4690 \\
\hline 24 & 62 & 70 & 3844 & 4900 & 4340 \\
\hline 25 & 68 & 80 & 4624 & 6400 & 5440 \\
\hline 26 & 63 & 70 & 3969 & 4900 & 4410 \\
\hline 27 & 56 & 80 & 3136 & 6400 & 4480 \\
\hline 28 & 48 & 80 & 2304 & 6400 & 3840 \\
\hline 29 & 50 & 80 & 2500 & 6400 & 4000 \\
\hline 30 & 67 & 80 & 4489 & 6400 & 5360 \\
\hline 31 & 66 & 75 & 4356 & 5625 & 4950 \\
\hline Jumlah & 1838 & 2170 & 110490 & 153450 & 129260 \\
\hline
\end{tabular}

Mengetahui apakah terdapat korelasi antara variabel x dan variabel y. Perhitungan rumusnya sebagai berikut:

$$
\begin{aligned}
& =\frac{31.129260-(1838)(2170)}{\sqrt{\left\{31 \sum 110490-(1838)^{2}\right\}\left\{31 \sum 153450-(2170)^{2}\right\}}} \\
& =\frac{4.007 .060-3.977 .460}{\sqrt{\sqrt{\{3.425 .190-3.378 .244\}\{4.756 .950-4.708 .900\}}}} \\
& =\frac{29.600}{\sqrt{(46.946)(48.050)}}=\frac{29.600}{\sqrt{225.575 .530}}=\frac{29.600}{47.495}=0.623
\end{aligned}
$$

Berdasarkan hasil perhitungan di atas, diperoleh nilai koefisien antara pengaruh penerapan metode Qiraati terhadap kemampuan membaca Al-Qur'an Aank sebesar $r_{x y}=0,62$. Hasil tersebut apabila dirubah kedalam skala konservati, 0,623 berada pada interval 0,40-0,70 yang berarti memiliki tingkat korelasi yang sedang atau cukup.

Nilai korelasi dari hasil perhitungan di atas, selanjutnya untuk menyatakan besar kecilnya sumbangan variabel $\mathrm{X}$ dan $\mathrm{Y}$ dapat ditentukan dengan rumus koefisien diterminan sebagai berikut.

$\mathrm{KD}=\mathrm{r}^{2} \times 100 \%=0,623^{2} \times 100 \%=0,3881 \times 100 \%=38,81 \%$

Hasil dari koefisien determinasi di atas, menunjukan pengaruh penerapan metode Qiraati terhadap kemampuan membaca Al-Qur'an anak usia 7-12 tahun di Taman Pendidikan Al-Qur'an (TPQ) Hidayatus Shibyan Desa Pegagan Lor Kecamatan Kapetakan Kabupaten Cirebon sebesar 38,81\% dan 61,19\% 
berhubungan dengan faktor lain, misalnya faktor lingkungan, keluarga, IQ dan sebagainya yang berpengaruh terhadap kemampuan membaca Al-Qur'an anak

Pengujian selanjutnya yaitu uji signifikansi yang berfungsi apabila peneliti ingin mencari makna hubungan variabel $\mathrm{X}$ terhadap $\mathrm{Y}$, maka hasil korelasi Pearson Product Moment tersebut diuji dengan uji signifikansi.

$t_{\text {hitung }}=\frac{r \sqrt{n-2}}{\sqrt{1-r^{2}}}=\frac{\mathbf{0 , 6 2} \sqrt{31-2}}{\sqrt{1-0,62^{2}}}=\frac{\mathbf{0 , 6 2} \sqrt{29}}{\sqrt{1-0,62^{2}}}=\frac{(\mathbf{0 , 6 2})(5,4)}{1-0,384}=\frac{3,348}{\mathbf{0 , 6 1 6}}=5,44$

Kaidah pengujian:

Mencari t Tabel dengan $\alpha=0,05$

$\mathrm{df}=(\mathrm{n}=2=31-2)=29$

$29=2,76$

Maka : $\mathrm{t}$ hitung $=5,44>\mathrm{t}$ tabel $=2,756$

Kriteria pengujian sebagai berikut :

Jika nilai t hitung > t tabel, Ha diterima.Jika nilai $\mathrm{t}$ hitung < $\mathrm{t}$ tabel, Ha ditolak.

Berdasarkan hasil diatas, dapat diketahui bahwa t hitung $(5,44)>t$ tabel (2,756), yang berarti Ha diterima dan Ho ditolak, sehingga dapat disimpulkan bahwa Ha yang menyatakan adanya pengaruh metode Qiraati terhadap kemampuan membaca Al-Qur'an anak usia 7-12 tahun di Taman Pendidikan AlQur'an (TPQ) Hidayatus Shibyan Desa Pegagan Lor Kecamatan Kapetakan Kabupaten Cirebon di diterima, sedangkan Ho yang menyatakan tidak adanyapengaruh metode Qiraati terhadap kemampuan membaca Al-Qur'an anak usia 7-12 tahun di Taman Pendidikan Al-Qur'an (TPQ) Hidayatus Shibyan Desa Pegagan Lor Kecamatan Kapetakan Kabupaten Cirebon ditolak.

\section{KESIMPULAN}

Berdasarkan hasil perhitungan peneliti mengenai pengaruh metode Qiraati terhadap kemampuan membaca Al-Qur'an anak usia 7-12 tahun di Taman Pendidikan Al-Qur'an (TPQ) Hidayatus Shibyan Desa Pegagan Lor Kecamatan Kapetakan Kabupaten Cirebon, maka peneliti dapat mengambil kesimpulan sebagai berikut : 
1. Penerapan metode Qiraati Taman Pendidikan Al-Qur'an (TPQ) Hidayatus Shibyan Desa Pegagan Lor Kecamatan Kapetakan Kabupaten Cirebon ini masuk dalam kategori baik, terbukti dengan rekapitulasi angket metode Qiraati diperoleh nilai sebesar 79, berada pada interval 75-100\%.

2. Kemampuan membaca Al-Qur'an anak Usia 7-12 tahun di Taman Pendidikan Al-Qur'an (TPQ) Hidayatus Shibyan Desa Pegagan Lor Kecamatan Kapetakan Kabupaten Cirebon termasuk dalam kategori baik, terbukti dengan rekapitulasi hasil tes kemampuan membaca Al-Qur'an ini, menunjukkannilai rata-ratanya yaitu 70karena berada pada interval $70-79$.

3. Pengaruh metode Qiraati terhadap kemampuan membaca Al-Qur'an anak Usia 7-12 tahun di Taman Pendidikan Al-Qur'an (TPQ) Hidayatus Shibyan Desa Pegagan Lor Kecamatan Kapetakan Kabupaten Cirebon adalah sebesar 0,62. Nilai korelasi tersebut termasuk pada kriteria sedang atau cukup, artinya penerapan metode Qiraati memiliki pengaruh yang sedang terhadap kemampuan membaca Al-Qur'an anak. Penerapan metode Qiraati ini memiliki kontribusi terhadap kemampuan membaca Al-Qur'an anak Usia 7-12 tahun di Taman Pendidikan Al-Qur'an (TPQ) Hidayatus Shibyan Desa Pegagan Lor Kecamatan Kapetakan Kabupaten Cirebon sebesar 38,81\% sedangkan sisanya61,19\% dipengaruhi oleh faktor lain.

\section{DAFTAR PUSTAKA}

Arikunto, Suharsimi. 2002. Prosedur Penulisan Suatu Pendekatan Praktek. Jakarta: Rineka Cipta.

Al-Khawali.2007. Mendidik Anak dengan Cerdas. Sukaharjo: Insan Kamil.

Anwar Rosihon. 2012. Ulumul Al-Qur'an. Bandung: Pustaka Setia.

Dachlan Bunyamin. 2001. Memahami Qiraati. Semarang: Yayasan Pendidikan Al-Qur'an Raudhatul Mujawwidin.

Depdikbud.1995. Kamus Besar Bahasa Indonesia

Desmita. 2013. Psikologi Perkembangan. Bandung: PT. Remaja Rosdakarya.

KEMENAG. 2009. Al-Qur'an. Semarang: Istana Karya Mulya 
Hafidz M. Nur Abdul. 1998. Mendidik Anak Bersama Rasulullah. Bandung: AlBayan

Murjito Imam. 2000. Pedoman Metode Praktis Pengajaran Ilmu Baca Al-Qur'an Qiraati. Semarang: Koordinator Pendidikan Al-Qur'an.

Sukmadinata Nana Syaodih. 2009. Metode Penelitian Pendidikan. Bandung: Remaja Rosdakarya

Rochman Elfi Yuliani Elfi. 2005. Psikologi Perkembangan. Yogyakarta: STAIN Ponorogo Press

Slameto. 2003. Belajar dan Faktor-Faktor yang Mempengaruhinya. Jakarta: PT. Rineka Cipta.

Suteja. 2015. Tafsir Tarbawi. Cirebon: Nurjati Press

Sudjono, Anas. 2014. Pengantar Statistika Pendidikan. Jakarta: Rajawali Pers.

Sugiyono. 2013. Metode Penulisan Pendidikan Pendekatan Kuantitatif, Kualitatif, dan $R \& D$. Bandung: Alfabeta.

Suryabrata Sumadi. 1998. Psikologi Pendidikan. Jakarta: Raja Grafindo Persada

Tampublon D.P. 2008. Kemampuan Membaca Teknik Membaca Efektif dan Efesien..Bandung: Angkasa

Tarigan Guntur Henry. 2008. Membaca Suatu Keterampilan Berbahasa.

Bandung: Percetakan Angkasa

Tatang S. 2012. Ilmu Pendidikan. Bandung: CV. Pustaka Setia. 